
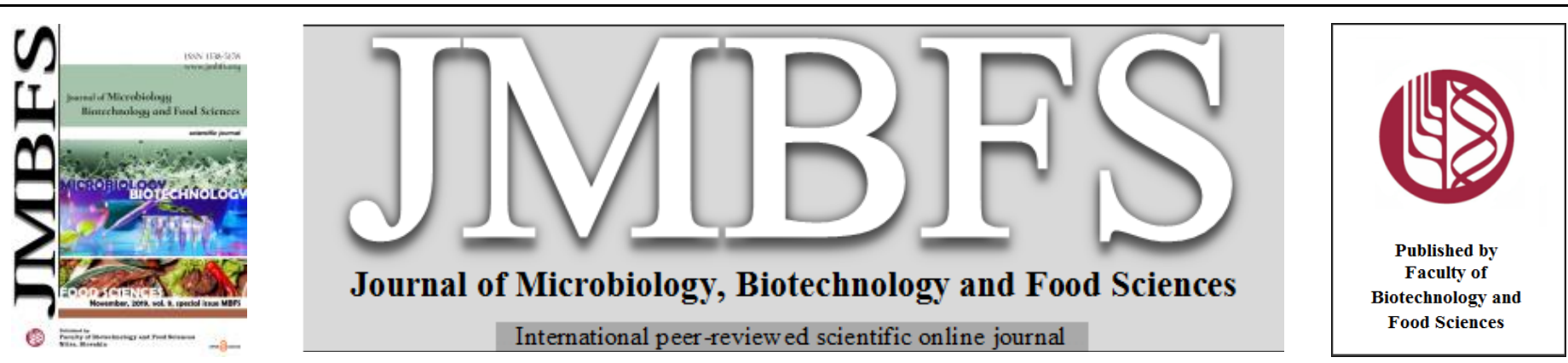

\title{
VARIABILITY OF SELECTED GENES IN RELATION TO THE PARAMETERS OF BONES IN LAYING HENS: A PILOT STUDY
}

\author{
Michala Steinerova*1, Cenek Horecky ${ }^{1}$, Eliska Horecka ${ }^{1}$, Ales Knoll ${ }^{1}$, Sarka Nedomova ${ }^{2}$, Ales Pavlik ${ }^{1}$
}

Address(es): Ing. Michala Steinerova

${ }^{1}$ Mendel University in Brno, Faculty of AgriSciences, Department of Animal Morphology, Physiology and Genetics, Zemědělská 1/1665, 613 00 Brno, Czech Republic, phone number: +420545131111.

${ }^{2}$ Mendel University in Brno, Faculty of AgriSciences, Department of Food Technology, Zemědělská 1/1665, 613 00 Brno, Czech Republic.

*Corresponding author: xsteine5@node.mendelu.cz

doi: 10.15414/jmbfs.2019.9.special.449-452

\section{ARTICLE INFO}

Received 29. 6. 2019

Revised 9. 9. 2019

Accepted 9. 9. 2019

Published 8. 11. 2019

Regular article open $\mathcal{O}$ access

\section{ABSTRACT}

The aim of the present study was to screen potential key genes associated with osteoporosis in laying hens. We performed association analysis of single nucleotide polymorphisms of selected genes encoding non-collagenous proteins (IBSP, SPP1, FN1, MEPE, DCN, THBS2) with parameters of bones in a group of ISA Brown laying hens. The surveyed parameters were bone breaking strength, length, width and bone mass. In this pilot study, nineteen samples for genes encoding non-collagenous proteins were tested. The polymorphisms were detected using PCR method and sequencing. Seven polymorphisms have been discovered in genes encoding noncollagenous proteins in the genes FN1 (c.7413A>G, c.7440+57G>A, c.7440+105G>A, c.7441-71T>C), DCN (c.158C > T) and $S P P 1$ $(c .362+117 \mathrm{G}>\mathrm{C}$, c.363-88G $>\mathrm{C})$, of which two of these polymorphisms were synonymous and five were in the intron. Despite the position of the found polymorphisms, no association with the mechanical parameters of the bones were found.

Keywords: osteoporosis, laying hens, polymorphism, bone, non-collagenous proteins

\section{INTRODUCTION}

The balance between processes in which osteoclasts continuously break down old bone and osteoblasts form new bone plays an important role in maintaining bone mass and skeletal strength (Costantini and Mäkitie, 2016). The characteristic microarchitectural deterioration that threatens bone strength and is accompanied by increased fracture risk is typical of an imbalance in the regulation of bone remodeling (Yang et al., 2013). This is the key pathophysiological mechanism of osteoporosis (Li et al., 2016). Osteoporosis has been described histologically as a decrease in the volume of structural cancellous and cortical bone within the skeleton and being defined as local or systemic deficiency in the quantity of fully mineralized structural bone (Cransberg et al., 2001). It is a complex disorder that is affected by number of factors including nutrition, sex, age, exercising, genetics and disease (Guo et al., 2017; Rocha-Braz and Ferraz-de-Souza, 2016).

Skeletal problems in hens caused by osteoporosis affect both welfare and economic aspects of production. Important role in the development of the skeletal system plays genetic composition, so an alternative to reducing this problem could be the research of polymorphisms for marker-assisted selection (MAS) (Fornari et al., 2012). Non-collagenous proteins (NCPs) are integral components of bone extracellular matrix (ECM) and exhibit multifunctional roles. These roles are critical for the bone resistance to fracture and bone quality. It has also been shown that by regulating the activity of osteoblast and osteoclast they affect bone modeling and subsequently alter their bone mass geometry. These proteins also affect mineralization of bone matrix, a key determinant of matrix quality and bone mechanical properties. NCPs impact hydroxyapatite crystallinity, formation of collagen fibrils and coordinate cell-matrix interactions. Therefore, by the effect of NCP on mineralization, they can affect the properties of bone material, such as hardness (Bailey et al., 2017; Morgan et al., 2015; Nikel et al., 2013).

Osteopontin (SPP1), integrin-binding sialoprotein (IBSP) and extracellular phosphoglycoprotein matrix (MEPE) common with dentin matrix protein 1 (DMP1) and dentin sialophosphoprotein (DSPP) belongs to a group of proteins known as SIBLINGS proteins. This group of NCPs as a component of the extracellular matrix and dentin is responsible of forming small integrin-binding ligand, N-linked glycoprotein (Malaval et al., 2008; Staines et al., 2012).

One of the major NCPs found in mineralized tissue is bone sialoprotein. The function of this acid glycoprotein is not fully understood. It appears to mediate adhesion between cellular surfaces and extracellular matrix components and stimulates hydroxyapatite formation in vitro. (Karmatschek et al., 1997; Yang et al, 1995). Secreted phosphoprotein-1 (SPP1), known as osteopontin, modulates both bone formation and resorption (Standal et al., 2004). Through binding with vitronectin receptor, anchoring of osteoclasts are formed to the bone remodeling matrix, where the process is related with bone formation (Chen et al., 2014). Fibronectin (FN1) is one of the first proteins produced by osteoblasts. It is a minor component of the bone matrix and directs the initial deposition of collagen fibrils. The presence of fibronectin is necessary to maintain the integrity of the collagen matrix (Boskey, 2013). By binding to other matrix proteins, it indirectly regulates mineralization and modifies their activities and regulates osteoblasts proliferation, differentiation and survival (Sroga and Vashishth, 2012). Matrix extracellular phosphoglycoprotein (MEPE) is protein, that are crucial for local matrix mineralization (Mäkitie et al., 2019). Its function in bone mineralization is confirmed by the fact that its expression is increased during osteoblast matrix mineralization. In the case of bone, MEPE is primarily expressed by osteocytes (Staines et al, 2012). Decorin belongs to a family of small leucine-rich proteoglycans (SLRPs) and is a key regulator of collagen fibril and matrix assembly (Robinson et al., 2017). Thrombospondin 2 (THBS2) belongs to the thrombospondin family and mediates cell-to-cell and cell-to-matrix interactions. Increase cortical bone density, acceleration of fracture healing and alters the pattern of load-induced bone formation are results of disrupted thrombospondin 2 expression. THBS2 participates in modulation the proliferation of osteoprogenitor cells and bone remodeling (Gao et al., 2017). For proper osteoclast function and differentiation is crucial the precise regulation of $\mathrm{Ca}^{2+}$ dynamics. (Kim et al., 2012). The plasma membrane calcium pump (PMCA) plays an important role in cellular calcium homeostasis (Ryan et al., 2015). The ATP2B1 gene, in hens located on chromosome 1, region $43273706-43305815$ bp, encodes plasma membrane calcium ATPase 1 (PMCA1) (Horecka et al. 2015; Long et al., 2017, Horecka et al., 2018).

Because most of studying proteins are involved in osteogenesis, bone remodelling and process of calcium metabolism, so polymorphisms of genes, encoding selected proteins, may play an important role in the pathogenesis of osteoporosis, by influencing protein formation and consequently bone formation. The aim of this work was to find out polymorphisms of selected genes and to identify possible associations with mechanical bone parameters that could be results of bone tissue disorders in laying hens. 


\section{MATERIAL AND METHODS}

Samples of isolated DNA from ISA Brown hens were tested. In non-collagenous proteins encoding genes, 19 samples of each gene were sequenced in the pilo study. Blood samples were taken from hens, kept in enriched cage technology according to 74/99/EC Council Directive. The hens were fed with a balanced layer feed (116 to 170 g.hen ${ }^{-1}$.day ${ }^{-1}$ ) that contained: $875 \mathrm{~g} \mathrm{~kg}^{-1}$ dry matter (energy content MEN 11.1 $\left.\mathrm{MJ} \mathrm{kg}^{-1}\right)$; crude protein $\left(170.7 \mathrm{~g} \mathrm{~kg}^{-1}\right)$; $\mathrm{Ca}\left(35.9 \mathrm{~g} \mathrm{~kg}^{-1}\right)$; and $\mathrm{P}$ $\left(6.3 \mathrm{~g} \mathrm{~kg}^{-1}\right)$. A constant light-dark cycle $(15: 9$, switching on at $04.00 \mathrm{~h}$ and switching off at $19.00 \mathrm{~h}$ ) was maintained as recommended in technological instructions for ISA Brown pullets. Hens were slaughtered at the average age of 26 weeks. Samples were taken immediately after slaughter by decapitation and blood was stabilized with heparin. Isolation of DNA was carried out from $100 \mu$ blood and commercially available DNA Lego kit (Top-Bio, Prague, Czech Republic) was used. The isolation proceeded according to the manufacturer's protocol. The analyzed bone physiological parameters were bone breaking strength of bones, bone length, width and bone mass, when analyses were performed on the femur. Right thigh was separated from the body of all animals and the femur was extracted out. After that all of muscles were removed. Bone strength was analyzed by universal testing machine TIRATEST 27025 (TIRA Maschinenbau GmbH, Schalkau, Germany) by three-point bending test. Bone length and width was assessed using Vernier calipers. Bone length was determined as the longest distance between the end of the distal and proximal epiphysis of the femur. The bone width was determined as the greatest distance between the facies cranialis and facies caudalis at the fracture point.

\section{IBSP, SPP1, FN1, MEPE, DCN, THBS2 and ATP2B1 genes testing}

For the PCR amplification specific oligonucleotide primers were designed (Table 1) using Oligo software v4.0 (Molecular Biology Insights, Inc., Colorado Springs, CO, USA) and cycling conditions were $94{ }^{\circ} \mathrm{C}$ for $3 \mathrm{~min}$, followed by 30 cycles of $94{ }^{\circ} \mathrm{C}$ for $1 \quad \mathrm{~min}, \quad 57 \quad{ }^{\circ} \mathrm{C}$ for $30 \quad \mathrm{~s}$, $72{ }^{\circ} \mathrm{C}$ for $1 \mathrm{~min}$, and then $10 \mathrm{~min}$ at $72{ }^{\circ} \mathrm{C}$ after the final cycle. PCR amplifications were performed using a ABI Veriti 96-Well thermocycler (Life Technologies, Applied Biosystems) in $10 \mu \mathrm{l}$ reaction volume.

The quality of PCR amplification and verifying of the correct PCR amplicon size was detected on $2.5 \%$ agarose gel stained with GoodView at $120 \mathrm{~V}$ for $30 \mathrm{~min}$ using TBE buffer and compared with weight marker 100 bp DNA Ladder (M100) (Thermo Fisher Scientific Inc., Waltham, USA). The PCR sequencing template was prepared by mixing: $0.2 \mu \mathrm{l}$ of the prepared PCR template (or $0.5 \mu \mathrm{l}$ with poor quality of PCR product), $0.5 \mu \mathrm{l}$ Terminator mix, $1.75 \mu \mathrm{l}$ Terminator $5 \mathrm{X}$ buffer $7.39 \mu \mathrm{DI} \mathrm{H} 2 \mathrm{O}$ and $0.16 \mu \mathrm{l} 10 \mu \mathrm{M}$ forward or reverse primer. Conditions of cycle sequencing was $96^{\circ} \mathrm{C}$ for $1 \mathrm{~min}$ followed by 25 cycles of $96^{\circ} \mathrm{C}$ for $10 \mathrm{~s}$, $50^{\circ} \mathrm{C}$ for $5 \mathrm{~s}$ and $60^{\circ} \mathrm{C}$ for $4 \mathrm{~min}$.

For purification was performed using BigDye XTerminator Purification kit (Life Technologies, Applied Biosystems) adding $5 \mu \mathrm{l}$ XTermination solution and $22.5 \mu \mathrm{l}$ Sam solution to each PCR sample, reaching a final volume of $37.5 \mu$ l. The samples were vortexed for $30 \mathrm{~min}$ and centrifuged at $3200 \mathrm{rpm}$ for $2 \mathrm{~min}$. The supernatant liquid was removed from each sample and transferred to a plate prior to being processed by an ABI PRISM 3500 DNA analyzer (Life Technologies, Applied Biosystems). Sequence alignments were performed using SeqScape v2.7 (Life Technologies, Applied Biosystems).

Table 1 IBSP, SPP1, FN1, MEPE, DCN, THBS2 primers

\begin{tabular}{|c|c|c|}
\hline Gene & Primer sequence & $\begin{array}{l}\text { Product size } \\
\text { (bp) }\end{array}$ \\
\hline \multirow{2}{*}{$I B S P$} & Forward: 5'-AGAGGAGCAGGATGTCAGTGT-3 ‘ & \multirow{2}{*}{491} \\
\hline & Reverse: 5'-CTTGTTGCTTTATTGCGTTTC-3' & \\
\hline \multirow{2}{*}{$S P P 1$} & Forward: 5'-TTTCTTTGCTTGTGCTTTATCA-3“ & \multirow{2}{*}{598} \\
\hline & Reverse: 5'-TCAAGCCCTCAATCCTAAATC-3“ & \\
\hline \multirow{2}{*}{ FN1 } & Forward: 5'-CTTGGACTTGCTGGTGCTGTA-3 ‘ & \multirow{2}{*}{676} \\
\hline & Reverse: 5'-GGTTTGTCTGTTGCCATTGC-3“ & \\
\hline \multirow{2}{*}{$M E P E$} & Forward: 5'-GAGCAGGATGGGGGCACT-3“ & \multirow{2}{*}{673} \\
\hline & Reverse: 5'-CCCCCGTGTGATGGTGAC-3“ & \\
\hline \multirow{2}{*}{$D C N$} & Forward: 5'-TGTGGCTTATTGTGTTGATTGTT-3 ‘ & \multirow{2}{*}{567} \\
\hline & Reverse: 5'-ATGAACACACTCCTGGGCTTA -3“ & \\
\hline \multirow{2}{*}{ THBS2 } & Forward: 5'-TTTATCCTTTCAGCCACCCT-3' & \multirow{2}{*}{320} \\
\hline & Reverse: 5'-ATTCTGCTGTTCTCTGCTTTCA-3“ & \\
\hline
\end{tabular}

\section{Statistical evaluation}

Obtained data were analyzed using Kruskal-Wallis test with genotype as an independent variable and bone breaking strength, bone length, width and bone mass as dependent variables. All statistical analyses were performed by STATISTICA 12 statistical software (StatSoft Inc., Tulsa, USA). The overall level of statistical significance was defined as $\mathrm{P}<0.05$.

\section{RESULTS}

Nineteen samples of each gene, which encoding non-collagenous proteins, were tested. Only one synonymous SNP (c.158C $>\mathrm{T})$ polymorphism were discovered in the $D C N$ gene. $M E P E$ and $I B S P$ genes showed non-specific amplification Therefore, these genes were excluded from the analysis. Another of the tested gene, the THBS2, was monomorphic.

\section{c. $7413 A>G$}

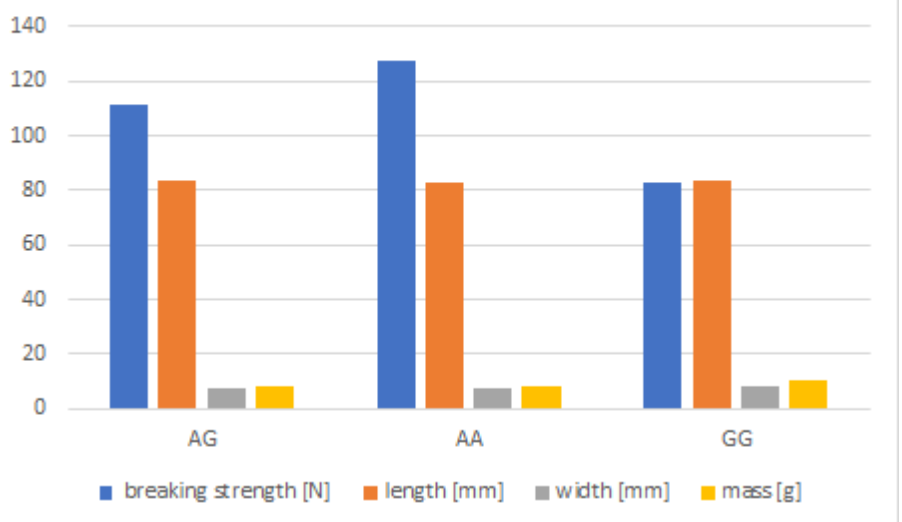

Figure 1 Effect of c.7413A $>$ G polymorphism $F N 1$ gene on femur parameters

In the case of the FN1 gene, a total of 4 polymorphisms were detected, three polymorphisms were found in the intron $(\mathrm{c} .7440+57 \mathrm{G}>\mathrm{A}, \mathrm{c} .7440+105 \mathrm{G}>\mathrm{A}$, c.7441-71T $>$ C) and one in the exon $($ c.7413A $>$ G), but this SNP was synonymous (not causing a change in the amino acid).

The allele frequencies of polymorphism in the $F N 1$ gene for c. $7440+105 \mathrm{G}>\mathrm{A}$ polymorphism were 0.10 for allele $A$ and 0.90 for $G$ allele with frequencies of the genotypes: 0.21 for $A G$ genotype, 0.79 for $G G$ genotype and $A A$ genotype were not found. The allele frequencies of polymorphism for c. $7440+57 \mathrm{G}>\mathrm{A}$, were 0.45 for allele $A$ and 0.55 for allele $G$. Frequencies of the genotypes were 0.11 for $A A$ genotype, 0.68 for $A G$ genotype and 0.21 for $G G$ genotype. Polymorphism of c.7441-71T $>\mathrm{C}$ showed allele frequencies: 0.58 for $T$ allele and 0.42 for $C$ allele, frequencies of genotypes were 0.22 for $T T$ genotype, 0.72 for $T C$ genotype and 0.06 for $C C$ genotype.

\section{c. $7440+105 G>A$}

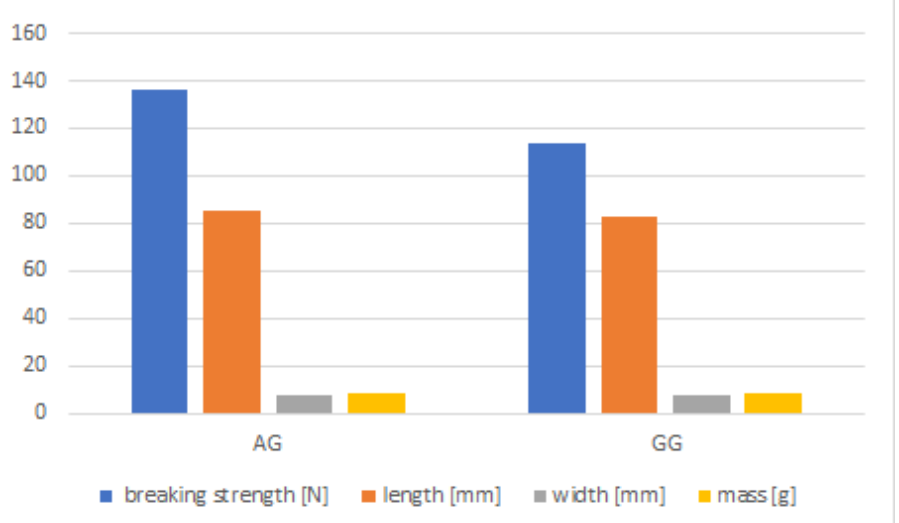

Figure 2 Effect of c. $7440+105 \mathrm{G}>\mathrm{A}$ polymorphism of $F N 1$ gene on femur parameters 


\section{c. $7440+57 \mathrm{G}>\mathrm{A} / \mathrm{c} .7441-71 \mathrm{~T}>\mathrm{C}$}

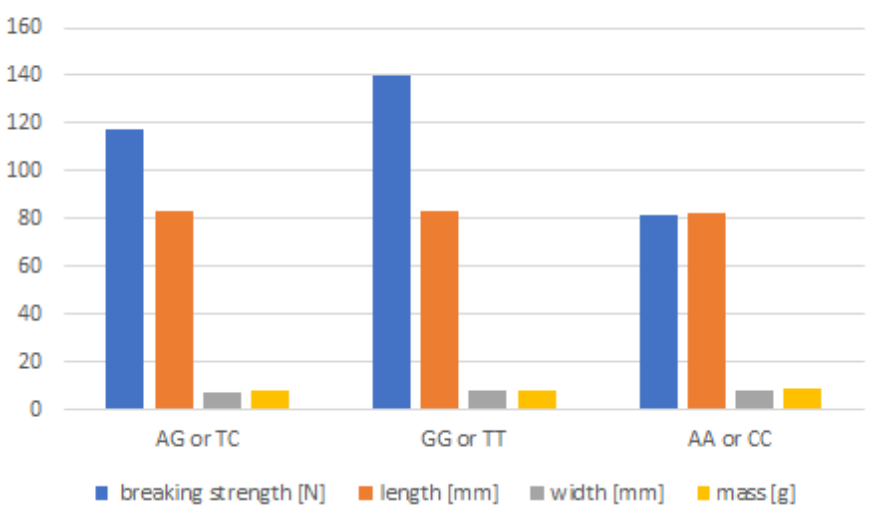

Figure 3 Effect of c. $7440+57 \mathrm{G}>\mathrm{A} / \mathrm{c} .7441-71 \mathrm{~T}>\mathrm{C}$ polymorphisms of $F N 1$ gene on femur parameters

A total of 2 polymorphisms in the intron $(\mathrm{c} .362+117 \mathrm{G}>\mathrm{C}$, c. $363-88 \mathrm{G}>\mathrm{C})$ were found in the selected section of the $S P P 1$ gene. In the $S P P 1$ gene, two intronic polymorphisms were found. The allele frequencies of c. $362+117 \mathrm{G}>\mathrm{C}$ were 0.19 for $C$ allele and 0.81 for $G$ allele, with genotype frequencies: 0.37 for $G C$ genotype, 0.63 for $G G$ genotype. $C C$ genotype were not found. Similar result showed polymorphism c.363-88G $>C$, where allele frequencies were 0.81 for $C$ allele and 0.19 for $G$ allele, with genotype frequencies: 0.63 for $C C$ genotype and 0.37 for $G C$ genotype. $G G$ genotype was not found.

\section{c. $362+117 \mathrm{G}>$ C $/$ c. $363-88 \mathrm{G}>\mathrm{C}$}

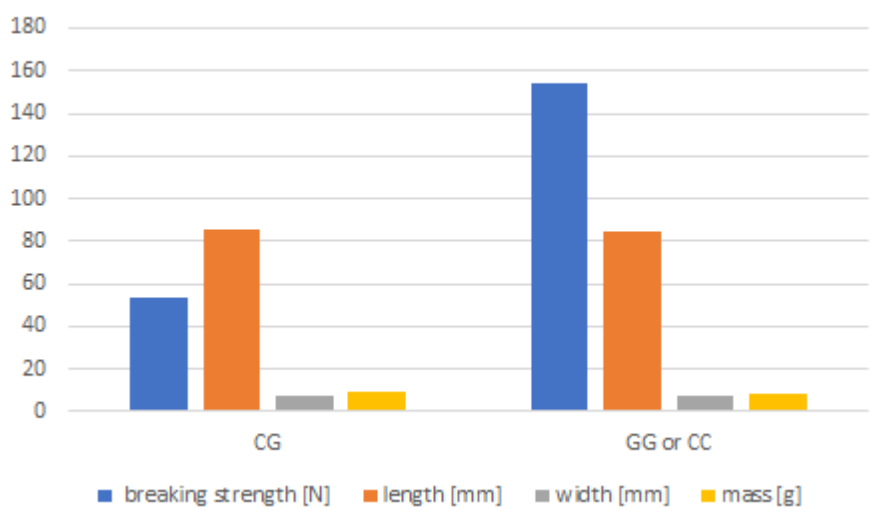

Figure 4 Effect of c.362+117G $>$ C/c. $363-88 \mathrm{G}>\mathrm{C}$ polymorphisms of $S P P 1$ gene on femur parameters

The femur breaking strength had minimum and maximum values of 39.47 and $271.67 \mathrm{~N}$ respectively. Range of absolute values for bone length was between 79.24 and $89.41 \mathrm{~mm}$, bone width 6.93 and $8,82 \mathrm{~mm}$, bone mass 6.86 and $9.45 \mathrm{~g}$. Despite some visible differences in bone parameters (Figure 1-4), the effects of polymorphisms were not proved.

\section{DISCUSSION}

This study was focused on finding polymorphisms that could be associate with bone parameters in laying hens, with a greater focus on non-collagenous proteins. There is no similar study focusing exclusively on noncollagenous proteins and very few studies to address gene polymorphisms associated with osteoporosis in laying hens. There are several studies on candidate genes and SNPs that are associated with osteoporosis in humans (Dastgheib et al., 2016; Liu et al., 2017; Qin et al., 2016).

Guo et al. (2017) conducted a genome association study (GWAS). This study included 1534 laying hens and examining the quality of their bones. They mapped the greatest heritability for bone mineral density on chromosome 1, with a region of $165-171 \mathrm{Mb}$ on GGA1 having a significant effect on bone quality. According to the NCBI genomic biology database, 4 genes (RANK, SERPINE3, INTS6 and POSTN) have been identified in this region and these genes might have an important effect on bone quality. They found nine SNPs that were associated with bone quality, and three of these genes (RANKL, ADAMTS and SOST) are known to be associated with human osteoporosis. This makes them suitable candidate genes for osteoporosis in laying hens. Johnsson et al. (2015) have identified several candidate genes affecting bone allocation and metabolism, which can also be used as a model for osteoporosis. They include in study a gene encoding a non-collagenous protein, osteonectin (SPARC). It contributes to mineralization by binding mineral crystals and it functions in bone remodeling.
SPARC is a possible candidate gene and a gene that can affect both total bone and modular tissue. Fornari et al. (2012) deal with one selected polymorphism (A211G). This polymorphism is found in the bone sialoprotein gene and its association with the skeletal structure in a paternal line of broilers has been investigated. Association analysis showed several significant indicators, including the tibia width indicator, where the analysis was highly significant Raymond et al. (2018) conducted an association study for bone strength in laying hens. Testing was performed on 752 laying hens belonging to the same population of pure lines. These laying hens were genotyped for a total of 580,961 SNPs, with 232,021 SNPs remaining after quality control. Associations with tibial breaking strength were tested for each SNP. A total of 52 SNPs were found that were significantly associated with the tibial breaking strength across chromosomes 1, 3, 8 and 16. Also, 5 distinct and novel QTLs on these chromosomes were identified, with the strongest association being detected in the QTL region at chromosome 8. Several candidate genes, including the BRD2 gene, were detected in these QTL regions. This gene is required for normal bone physiology.

Most of the detected SNPs in genes encoding non-collagenous proteins were found in the non-coding regions of the genes, introns. Since introns belong to the non-coding region of DNA, the polymorphisms found in this region may not seem to have the corresponding value.

However, intronic SNPs may potentially affect mRNA splicing. If the mRNA from a given gene can undergo alternative splicing, then this intron may be included in an alternative form of that protein, thereby affecting the expression of that protein and subsequently leading to abnormalities in the respective phenotype (Cai et al., 2015; Cooper, 2010).

Most of the reported mutations are located in exonic sequences, although that $>90 \%$ of the gene sequences contain introns. However, the number of new pathogenic variants increases. The mutations that affect splicing disrupt highly conserved donor and acceptor sites at the exon-intron junctions, the branch-point sequence, and the polypyrimidine tract with various consequences. These consequences include exon skipping and the activation of cryptic splice sites. Recently, attention has been focused on mutations deep in intronic sequences, which affect exonic and intronic splicing enhancers or silencers. These less well-conserved auxiliary splicing sequences help to recognize and bind specific splicing regulatory proteins (Seo et al., 2013). Therefore, SNPs not only in exons can play an important role in identifying specific associations.

\section{CONCLUSION}

Genetic factors are the basis for variability in bird susceptibility to osteoporosis and bone fractures. In laying hen breeds, skeletal problems are becoming an increasingly common problem, and it is known, that this problem is not only confined to conventional battery cages. If there is no reassessment of the approach to breeding laying hens, the problem of skeletal damage could be aggravated, especially by increasing production pressure. Studies of markers that could affect bone parameters, especially their strength, can contribute to both welfare and economic aspects of production. Therefore, this work tried to focus on the search for SNPs that could affect the monitored bone indicators. In genes encoding non-collagenous proteins there was no polymorphism that affected bone parameters in animals of the present study. Therefore, for some genes, it would be advisable to extend the study to other regions of the genes that would be explored, and methods optimized to allow further analysis. Also, the study could be extended to include new genes that are mentioned as candidates by the authors.

Acknowledgments: The research was financially supported by the Internal Grant Agency of the Faculty of AgriSciences, Mendel University in Brno (AFIGA2019-IP 009).

\section{REFERENCES}

BAILEY, S., KARSENTY, G., GUNDBERG, C., \& VASHISHTH, D. (2017) Osteocalcin and osteopontin influence bone morphology and mechanical properties. Annals of New York Academy of Sciences, 1409(1), 79-84. http://dx.doi.org/10.1111/nyas.13470

BOSKEY, A. L. (2013). Bone composition: relationship to bone fragility and antiosteoporotic drug effect. Bonekey Reports, 2, 447. http://dx.doi.org/10.1038/bonekey.2013.181

CAI, H., ZHOU, Y., JIA, W., ZHANG, B., LAN, X., LEI, CH., FANG, X., \& CHEN, H. (2015). Effect of SNPs and alternative splicing within $H G F$ gene on its expression patterns in Qinchuan cattle. Journal of Animal Science and Biotechnology, 6, 55. http://dx.doi.org/10.1186/s40104-015-0059-3

COOPER, D. N. (2010). Functional intronic polymorphisms: Buried treasure awaiting discovery within our genes. Human Genomics, 4(5), 284-288. http://dx.doi.org/10.1186/1479-7364-4-5-284

COSTANTINI, A., \& MÄKITIE, O. (2016). Value of rare low bone mass

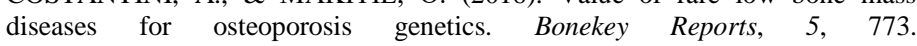
http://dx.doi.org/10.1038/bonekey.2015.143 
CRANSBERG, P. H., PARKINSON, G. B., WILSON, S., \& THORP, B. H. (2001). Sequential studies of skeletal calcium reserves and structural bone volume in a commercial layer flock. British Poultry Science, 42(2), 260-265. http://dx.doi.org/10.1080/00071660120048528

DASTGHEIB, S. A., GARTLAND, A., TABEI, S. M., OMRANI, G. R., \& TEARE, M. D. (2016). A Candidate Gene Association Study of Bone Mineral Density in an Iranian Population. Frontiers in endocrinology. 7, 141 http://dx.doi.org/10.3389/fendo.2016.00141

FORNARI, M. B., NEIS, K. L., MARCHESI, J. A. P., LEDUR, M. C., SOCCOL, V. T., \& PEIXOTO, J. DE O. (2012). Association of the A211G polymorphism in the bone sialoprotein gene with skeletal structure in a paternal broiler line. Poultry Science Journal, Supplement 1.

GAO, F., XU, F., WU, D., CHENG, J., \& XIA, P. (2017). Identification of novel genes associated with fracture healing in osteoporosis induced by $\mathrm{Krm} 2$ overexpression or Lrp5 deficiency. Molecular Medicine Reports, 15(6), 39693976. http://dx.doi.org/10.3892/mmr.2017.6544

GUO, J., SUN, C., QU, L., SHEN, M., DOU, T., MA, M., WANG, K., \& YANG, N. (2017). Genetic architecture of bone quality variation in layer chickens revealed by a genome-wide association study. Scientific Reports, 7 , 45317. http://dx.doi.org/10.1038/srep45317

HORECKA, E., HORECKY, C., KOVARIKOVA, L., MUSILOVA, A. KNOLL, A., \& PAVLIK, A. (2015). Polymorphisms in plasma membrane calcium-transporting ATPase 1 (ATP2B1) gene in hens. In MendelNet 2015 (Proceedings of International PhD Students Conference) Brno: Mende University in Brno, 458-461. ISBN 978-80-7509-363-9.

HORECKA, E., HORECKY, C., KOVARIKOVA, L., MUSILOVA, A. KNOLL, A., NEDOMOVA, S., \& PAVLIK, A. (2018). Association between single nucleotide polymorphism of $A T P 2 B 1$ gene and bone parameters of laying hens. Avian Biology Science, 11(3), 178-182 http://dx.doi.org/10.3184/175815618X15269357438898.

CHEN, J. H., CHEN, Y. CH., MAO, CH. L., CHIOU, J. M., TSAO, CH. K., \& TSAI, K. S. (2014). Association between Secreted Phosphoprotein-1 (SPP1) Polymorphisms and Low Bone Mineral Density in Women. Public Library of Science One, 9(5), e97428. http://dx.doi.org/10.1371/journal.pone.0097428 JOHNSSON, M., JONSSON, K. B., ANDERSSON, L., JENSEN, P., \& WRIGHT, D. (2015). Genetic Regulation of Bone Metabolism in the Chicken Similarities and Differences to Mammalian Systems. Public Library of Science Genetics, 11(5), e1005250. http://dx.doi.org/10.1371/journal.pgen.1005250

KARMATSCHEK, M., MAIER, I., SEIBEL, M. J., WOITGE, H. W., ZIEGLER, R., \& ARMBRUSTER, F. P. (1997). Improved purification of human bone sialoprotein and development of a homologous radioimmunoassay. Clinical Chemistry, 43(11), 2076-2082

KIM, H. J., PRASAD, V., HYUNG, S. W., LEE, Z. H., LEE, S. W. BHARGAVA, A., PEARCE, D., LEE, Y., \& KIM, H. H. (2012). Plasma membrane calcium ATPase regulates bone mass by fine-tuning osteoclast differentiation and survival. Journal of Cell Biology, 199(7), 1145-1158. http://dx.doi.org/10.1083/jcb.201204067

LI, J. J., WANG, B. Q., FEI, Q., YANG, Y., \& LI, D. (2016). Identification of candidate genes in osteoporosis by integrated microarray analysis. Bone \& Joint Research, 5(12), 594-601. http://dx.doi.org/10.1302/2046-3758.512.BJR-20160073.R1

LIU, K., TAN, L. J., WANG, P., CHEN, X. D., ZHU, L. H., ZENG, Q., HU, Y., \& DENG, H. W. (2017). Functional relevance for associations between osteoporosis and genetic variants. Public Library of Science One, 12(4), E0174808. http://dx.doi.org/10.1371/journal.pone.0174808

LONG, Y., XIA, J. Y., CHEN, S. W., GAO, CH. L., LIANG, G. N., HE, X. M., WU, J., JIANG, CH. X., LIU, X., HUANG, W., WAN, Q., \& XU, Y. (2017). ATP2B1 gene Silencing Increases Insulin Sensitivity through Facilitating Akt Activation via the $\mathrm{Ca} 2+/$ calmodulin Signaling Pathway and $\mathrm{Ca} 2+$-associated eNOS Activation in Endothelial Cells. International Journal of Biological Sciences, 13(9), 1203-1212. http://dx.doi.org/10.7150/ijbs.19666

MÄKITIE, R. E., COSTANTINI, A., KÄMPE, A., ALM, J. J., \& MÄKITIE, O. (2019). New insights into monogenic causes of osteoporosis. Frontiers in Endocrinology (Lausanne), 10, 70. http://dx.doi.org/10.3389/fendo.2019.00070 MALAVAL, L., LWADE-GUÉYE, N. M., BOUDIFFA, M., FEI, J., ZIRNGIBL, R., CHEN, F., LAROCHE, N., ROUX, J. P., BURT-PICHAT, B. DUBOEUF, F., BOIVIN, G., JURDIC, P., LAFAGE-PROUST, M. H., AMÉDÉE, J., VICO, L., ROSSANT J., \& AUBIN, J. E. (2008). Bone sialoprotein plays a functional role in bone formation and osteoclastogenesis. Journal of Experimental Medicine, 205(5), 1145-1153. http://dx.doi.org/10.1084/jem.20071294

MORGAN, S., POUNDARIK, A. A., \& VASHISHTH, D. (2015). Do noncollagenous proteins affect skeletal mechanical properties? Calcified Tissue International, 97(3), 281-291. http://dx.doi.org/10.1007/s00223-015-0016-3

NIKEL, O., LAURENCIN, D., MCCALLUM, S. A., GUNDBERG, C. M. \& VASHISHTH, D. (2013). NMR investigation of the role of osteocalcin and osteopontin at the organic-inorganic interface in bone. Langmuir, 29(45), 1387313882. http://dx.doi.org/10.1021/la403203w

QIN, L., LIU, Y., WANG, Y., WU, G., CHEN, J., YE, W., YANG, J., \& HUANG, Q. (2016). Computational characterization of osteoporosis associated
SNP and genes identified by genome-wide association studies. Public Library of Science One, 11(3), e0150070. http://dx.doi.org/10.1371/journal.pone.0150070

RAYMOND, B., JOHANSSON, A. M., MCCORMACK, H. A., FLEMING, R. H., SCHMUTZ, M., DUNN, I. CH., \& DE KONING, D. J. (2018). Genome-wide association study for bone strength in laying hens. Animal Science, 96(7), 2525 2535. http://dx.doi.org/10.1093/jas/sky157

ROBINSON, K. A., SUN. M., BARNUM, C. E., WEISS, S. N., HUEGEL, J., SHETYE, S. S., LIN, L., SAEZ, D., ADAMS, S. M., IOZZO, R. V., SOSLOWSKY, L. J., \& BIRK, D. E. (2017). Decorin and biglycan are necessary for maintaining collagen fibril structure, fiber realignment, and mechanical properties of mature tendons. Matrix Biology, 64, 81-93. http://dx.doi.org/10.1016/j.matbio.2017.08.004

ROCHA-BRAZ, M. G., \& FERRAZ-DE-SOUZA, B. (2016). Genetics of osteoporosis: searching for candidate genes for bone fragility. Archives of Endocrinology and Metabolism, 60(4), 391-401. http://dx.doi.org/10.1590/23593997000000178

SEO, S., TAKAYAMA, K., UNO, K., OHI, K., HASHIMOTO, R. NISHIZAWA, D., IKEDA, K., OZAKI, N., NABESHIMA, T., MIYAMOTO, Y., \& NITTA, A. (2013). Functional analysis of deep intronic SNP rs 13438494 in intron 24 of PCLO gene. Public Library of Science One, 8(10), e76960. http://dx.doi.org/10.1371/journal.pone.0076960

SROGA, G. E., \& VASHISHTH, D. (2012). Effect of bone matrix proteins on fracture and fragility in osteoporosis. Current Osteoporosis Reports, 10(2), 141150. http://dx.doi.org/10.1007/s11914-012-0103-6

STAINES, K. A., MACKENZIE, N. C. W., CLARKIN, C. E., ZELENCHUK, L., ROWE, P. S., MACRAE, V. E., \& FARQUHARSON, C. (2012). MEPE is a novel regulator of growth plate cartilage mineralization. Bone, 51(3), 418-430. http://dx.doi.org/10.1016/j.bone.2012.06.022

STAINES, K. A., MACRAE, V., \& FARQUHARSON, C. (2012). The importance of the SIBLING family proteins on skeletal mineralisation and bone remodeling. Journal of Endocrinology, 214, 241-255. http://dx.doi.org/10.1530/JOE-12-0143

STANDAL, T., BORSET, M., \& SUNDAN, A. (2004). Role of osteopontin in adhesion, migration, cell survival and bone remodeling. Experimental Oncology, 26(3), 179-184.

YANG, H., ZHANG, B., ZHU, J., LIU, D., GUAN, F., \& HE, X. (2013) Contributes to Bone Mineral Density and Osteoporosis Susceptibility in Postmenopausal Women of Chinese Han Population. Public Library of Science One, 5(11), e80165. http://dx.doi.org/10.1371/journal.pone.0080165

YANG, R., GOTOH, Y., MOORE, M. A., RAFIDI, K., \& GERSTENFELD, L. C. (1995). Characterization of an Avian Bone Sialoprotein (BSP) cDNA Comparisons to Mammalian BSP and Identification of Conserved Structura Domains. Journal of Bone and Mineral Research, 10(4), 632-640. http://dx.doi.org/10.1002/jbmr.5650100417 